\title{
Effect of varietal performance on growth attributes and yields of lentil varieties under red and lateritic soil of West Bengal
}

\author{
U. Biswas, G. Mandi, S. Bandyopadhyay, B. K. Saren and Kanu Murmu* \\ Department of Agronomy, Bidhan Chandra Krishi Viswavidyalaya, Mohanpur, Nadia, West Bengal- 741252, \\ INDIA \\ Department of ASEPAN, Palli Shiksha Bhavana, Visva-Bharati, Sriniketan, Birbhum, West Bengal-731236,INDIA \\ *Corresponding author. E-mail: kanumurmu@gmail.com
}

Received: December 10, 2016; Revised received: May 4, 2017; Accepted: January 20, 2018

\begin{abstract}
A field experiment was conducted during rabi season of 2013-14 and 2014-15 at Agriculture Farm of Palli Siksha Bhavana (Institute of Agriculture), Visva-Bharati, Sriniketan, West Bengal to find out the varietal performance of different promising entries of lentil on growth attributes and yield. Tendifferent varieties viz. Subrata, Asha, Ranjan, HUL 57, BM 6, BM 7, PL 406, KLS 218, Moitree and PL 6 was studied in a randomized block design (RBD), replicated thrice. Different growth and yield attributes were measured in the experiment to find out the suitable variety of lentil for the red and lateritic soil zone of West Bengal. The lentil variety PL-406 showed maximum growth potentiality among the other varieties just followed by another long duration lentil variety KLS-218. The lentil variety PL406 showed maximum growth potentiality among the other varieties just followed by another long duration variety KLS 218. Highest grain yield was obtained from the variety Ranjan (789 kg ha-1) followed by the variety PL 406 (785 $\left.\mathrm{kg} \mathrm{ha}^{-1}\right)$ and KLS $218\left(783 \mathrm{~kg} \mathrm{ha}^{-1}\right)$ respectively. From the result of the present experiment, it can be concluded that the variety PL 406 gave maximum vegetative growth, whereas the variety Ranjan produce maximum yield and found most potential variety among other lentil varieties under red and lateritic soil of West Bengal.
\end{abstract}

Keywords: Lentil, Varietal performance, Yield attributes

\section{INTRODUCTION}

Lentil (Lens culinaris) is the fourth most important pulse crop of the world after beans, pea and chickpea. It is a bushy annual plant of the legume family, grown for its lens-shaped seeds. It is the important pulse crop mainly grown on residual soil moisture and prominent source of vegetable protein (Singh et al., 2011). In India, lentil occupies 1.51 million ha area with a production of 1.13 million ton. Average annual growth in area, production and yield of lentil has increased steadily from 2008 to 2014 in the tune of $2.5 \%, 7.9 \%$ and $5.7 \%$ respectively (DAC, 2014). Besides fixing atmospheric $\mathrm{N}$ and benefitting the succeeding crop with residual nitrogen in soil, lentils also adapted to local climatic and soil fertility conditions (Srinivasarao et $a l ., 2012)$. Lentil has the potentiality to fix up to $120 \mathrm{~kg}$ $\mathrm{N} \mathrm{ha}^{-1}$ in the soil (Ali et al., 1998). Lentil has a very good potential for increasing farm income as well as cropping intensity (Das et al., 2013). Lentil is a major legume crop and main source of dietary protein in eastern region (Ali et al., 2012 and Singh et al., 2013). Lentil is one of the most nutritious cool season legumes and ranks next only to Chickpea in India. Lentil contains about $24 \%$ - 26\% protein, $1.3 \%$ fat, $2.1 \%$ minerals, $3.2 \%$ fiber and $57 \%$ carbohydrate (Ali et al.,
2012). Lentils are deficient in two essential amino acids, methionine and cysteine. Lentil seed contain protein 2.5 per cent, fat 1.5 per cent and carbohydrates 56.6 per cent (Reddy, 2012). Lentil has high saponin content (3.7-4.6 $\mathrm{g} \mathrm{kg}^{-1}$ seed), which reduces the cholesterol levels in the blood. Lentil is not only grown as an important rabi pulse in West Bengal, it is a potential crop in the adjoining provinces of India (Bihar, Jharkhand and Uttaranchal) as well as abroad (Nepal, Pakistan and Bangladesh) because of consumer's preference (Roy et al., 2009). In West Bengal lentil seeds are generally broadcasted (as paira crop) in the standing crop of rice 7-10 days before harvesting (relay cropping) to capitalize on residual moisture and ensure timely sowing as well as to get guarantee for germination and skipping off the tillage operations during lentil growing. In West Bengal, it is grown in 65.46 thousand ha area producing 62.74 thousand tons of grains and productivity of $959 \mathrm{~kg} \mathrm{ha}^{-1}$ (IIPR, 2015). The response of promising lentil varieties viz. PL-639, B-77 (Asha), WBL-58 (Subrata) and WBL-77 (Moitree) were studied in West Bengal; among this varieties, Moitree (WBL-77) yielded the highest (1332.71 kgha ${ }^{1}$ ), exhibiting yield advantages to the tune of about 49$70 \%$ over the others and its superiority could be ex- 
plained on the basis of higher podding potentiality (110.63 pods plant ${ }^{-1}$ ) (Roy et al., 2009). So, we have to introduce some good promising varieties of lentil, which will be profitable to the farmers of West Bengal. The objectives of the experiment were to find out the suitable varieties of lentil under the red and lateritic soil, to study the growth and productivity of different lentil varieties under the red and lateritic soil and to compare the existing varieties between the treatments.

\section{MATERIALS AND METHODS}

A field experiment was conducted to performance of different lentil varieties under red and lateritic soil of West Bengal during rabi season of 2013-2014 and 2014-15 at Agriculture farm (D-5 East Plot), Palli Siksha Bhavana (Institute of Agriculture), Visva-Bharati, Sriniketan, Birbhum, West Bengal in red and lateritic soil. The farm was situated at $23^{\circ} 39^{\prime} \mathrm{N}$ latitude and $87^{\circ} 42^{\prime} \mathrm{E}$ longitude with an average altitude of $58.90 \mathrm{~m}$ above mean sea level under sub-humid, semi arid region of West Bengal.

The soil analysis revealed that the soil of the experimental field was loamy sand in texture, well drained with low level of organic carbon $(0.42 \%)$, available nitrogen $\left(215.74 \mathrm{~kg} \mathrm{ha}^{-1}\right)$ and potassium $(146.54 \mathrm{~kg} \mathrm{ha}$ $\left.{ }^{1}\right)$ content and medium in available phosphorus (29.48 $\left.\mathrm{kg} \mathrm{ha}^{-1}\right)$. The soil was slightly acidic $(\mathrm{pH} \mathrm{565)}$ in reaction with bulk density $1.60 \mathrm{~g} \mathrm{cc}^{-1}$.Soil samples were collected from the plough layer at the beginning of the experiment. These samples were air dried, ground, sieved and then used in chemical analysis for determination of soil organic-C content, available $\mathrm{N}, \mathrm{P}$ and $\mathrm{K}$ content of the soil. Organic carbon content in the soil was determined by the volumetric weight combustion method commonly known as Walkley Black method given by Walkley and Black (1934). Available N content of soil samples was estimated by alkaline permanganate method given by Subbiah and Asija (1956) and presented as $\mathrm{kg} \mathrm{N} \mathrm{ha}^{-1}$. Available $\mathrm{P}$ content of the soil samples was estimated by the Olsen method (Olsen et al., 1954). Available K content was determined by Flame photometer method given by Muhr et al. (1965). Soil $\mathrm{pH}$ content was determined with the help of $\mathrm{pH}$ meter in $1: 2.5$ ratio of soil : water suspension as recommended by Jackson (1973). Bulk density was estimated by core sampling method.

Treatments comprised of ten different varieties of lentil viz. Subrata, Asha, Ranjan, HUL-57, BM-6, BM-7, PL-406, KLS-218, Moitree and PL-6 was studied in a randomized block design (RBD) with three replications. The treatments were allocated randomly to different plots with the help of random number table (Fisher, R.A. and Yates, F. 1953) and the data were analysed by ANOVA, and ranked by using the critical differences (CD) at 5\% level. Pooled values of two years data for different parameters are used.. To obtain a fine seed bed to sowing the lentil crop seed the land was ploughed two times with the help of tractor with cultivator, and two times with tractor with rotavator. Then the clods, stones and weeds were removed from the experimental field. Planking was done to break clods and level the field after final tillage. Finally, the layout was made as per design of the experiment. Bunds and irrigation channel were made with 0.5 and $1.0 \mathrm{~m}$ wide, respectively. The size of plot was $4 \mathrm{~m} \times 3 \mathrm{~m}$ respectively. The seed was inoculated properly with the culture of Rhizobium $s p$. A general recommended dose of $\mathrm{N}: \mathrm{P}_{2} \mathrm{O}_{5}: \mathrm{K}_{2} \mathrm{O}$ for rainfed lentil was applied uniformly to each plot at the rate of 20:40:40 $\mathrm{kg} \mathrm{ha}^{-1}$. It was then thoroughly mixed with the soil. All the fertilizers were given in the plots uniformly at the time of sowing. Sowing was done uniformly with 3-4 $\mathrm{cm}$ depth in all the plots manually by using $30 \mathrm{~kg}$ seeds $\mathrm{ha}^{-1}$ with a spacing of $25 \mathrm{~cm} \mathrm{x} 3 \mathrm{~cm}$. All the standard agronomic management practices were followed as per the requirements. In this experiment Maximum plant height $(\mathrm{cm})$, number of branches plant ${ }^{-1}$, dry matter accumulation $\left(\mathrm{g} \mathrm{m}^{-2}\right)$, leaf area index, seed yield $\left(\mathrm{kg} \mathrm{ha}^{-1}\right)$, pod yield $\left(\mathrm{kg} \mathrm{ha}^{-1}\right)$, stover yield $\left(\mathrm{kg} \mathrm{ha}^{-1}\right)$, biological yield $\left(\mathrm{kg} \mathrm{ha}^{-1}\right)$, shelling percentage (\%) and harvest index (\%) were measured.

\section{RESULTS AND DISCUSSION}

Growth attributes: The data of two years showed that among the all lentil varieties, the highest plant height was observed under the variety PL-406 (37.74 and $40.23 \mathrm{~cm}$ in both of the year respectively) which was immediately followed by KLS-218 (37.17 and 39.62 $\mathrm{cm}$ in 2013-14 and 2014-15) and Ranjan (36.62 and $39.06 \mathrm{~cm}$ in 2013-14 and 2014-15). The variety BM-6 produced the lowest plant height in both of the year (Table 1). The varieties PL-6, Moitree, BM-7, Asha, Subrata, HUL-57 and BM-6 can be grouped as lower plant height, where as PL-406, KLS-218 and Ranjan produced higher plant height

The dry matter accumulation in lentil increased with advancement of the crop age under all the treatments. The highest dry weight accumulation was observed in variety PL-406 (212.56 and $247.53 \mathrm{~g} \mathrm{~m}^{-2}$ in 2013-14 and 2014-15), where the lowest dry weight accumulation was found in BM-6. From the table 1, it can be stated that the variety KLS-218 and Ranjan were statistically at par with the variety PL-406 in relation to dry weight accumulation Kundu et al. (2014) observed significant differences in plant height, dry matter accumulation of the lentil crop variety from a two consecutive years study (2012-13 and 2013-14) to assess the performances of sixteen pre-released and two standard varieties of bold seeded lentil for their growth.

The highest number of branches plant ${ }^{-1}$ was obtained from the cultivar PL-406 (5.88 and 6.27 in two consecutive years respectively), which was statistically at par with cultivars KLS-218and Ranjan. The lowest number of branches plant ${ }^{-1}$ was recorded from the cultivar 
Table 1. Effect of growth attributes of different varieties of lentil

\begin{tabular}{|c|c|c|c|c|c|c|c|c|}
\hline \multirow[t]{2}{*}{ Treatment } & \multicolumn{2}{|c|}{$\begin{array}{l}\text { Plant Height } \\
90 \text { DAS }(\mathrm{cm})\end{array}$} & \multicolumn{2}{|c|}{$\begin{array}{ll}\begin{array}{l}\text { Number } \\
\text { branchplant }^{-1}\end{array} & \text { of } \\
\end{array}$} & \multicolumn{2}{|c|}{$\begin{array}{l}\text { Dry Weight Accumu- } \\
\text { lation }\left(\mathrm{gm}^{-2}\right)\end{array}$} & \multicolumn{2}{|c|}{$\begin{array}{l}\text { Leaf Area Index } \\
\text { (90 DAS) }\end{array}$} \\
\hline & 2013-14 & 2014-15 & 2013-14 & 2014-15 & 2013-14 & 2014-15 & 2013-14 & 2014-15 \\
\hline Subrata & 31.94 & 33.99 & 5.50 & 5.87 & 162.93 & 193.03 & 1.29 & 1.30 \\
\hline Asha & 32.02 & 34.14 & 5.47 & 5.84 & 165.94 & 195.69 & 1.28 & 1.30 \\
\hline Ranjan & 36.62 & 39.06 & 5.82 & 6.21 & 191.51 & 227.88 & 1.34 & 1.36 \\
\hline HUL-57 & 31.58 & 33.96 & 5.43 & 5.79 & 166.88 & 195.46 & 1.26 & 1.29 \\
\hline BM-6 & 30.68 & 32.99 & 5.36 & 5.70 & 156.03 & 182.38 & 1.13 & 1.14 \\
\hline BM-7 & 32.26 & 34.36 & 5.59 & 5.98 & 191.35 & 221.19 & 1.24 & 1.26 \\
\hline PL-406 & 37.74 & 40.23 & 5.88 & 6.27 & 212.56 & 247.53 & 1.46 & 1.48 \\
\hline KLS-218 & 37.17 & 39.62 & 5.83 & 6.21 & 210.30 & 244.82 & 1.35 & 1.38 \\
\hline Moitree & 33.69 & 35.98 & 5.56 & 5.91 & 189.59 & 223.24 & 1.29 & 1.31 \\
\hline PL-6 & 34.05 & 36.21 & 5.53 & 5.90 & 183.98 & 218.25 & 1.28 & 1.29 \\
\hline $\operatorname{S.Em}( \pm)$ & 0.98 & 0.94 & 0.09 & 0.10 & 6.86 & 7.06 & 0.05 & 0.05 \\
\hline $\mathrm{CD}(\mathrm{P}=0.05)$ & 2.91 & 2.79 & 0.28 & 0.30 & 20.37 & 20.97 & 0.15 & 0.16 \\
\hline $\mathrm{CV} \%$ & 5.03 & 4.52 & 2.88 & 2.97 & 6.49 & 6.44 & 6.59 & 6.97 \\
\hline
\end{tabular}

BM-6 (5.36 and $5.70 \mathrm{~cm}$ in 2013-14 and 2014-15) (Table 1). Differential performance by the different lentil varieties may be due to genetic variability adaptability, morphological features, and physiological factors during the cropping period.

The highest leaf area index (LAI) was recorded in PL406 (1.46 and 1.48 in 2013-14 and 2014-15 respectively), which was immediately followed by KLS-218and Ranjan. From the Table 1, we can observe that; as well as plant height and dry weight accumulation, the lowest leaf area index was recorded from the cultivar BM-6.

Yield and yield attributes: Table 2 shows that among all tested varieties, Ranjan cultivar produced significantly higher grain yield for both of the years of experiment (789 and $809 \mathrm{~kg} \mathrm{ha}^{-1}$ in 2013-14 and 2014-15 respectively) whereas BM-6 showed the lowest grain yield (606 and $617 \mathrm{~kg} \mathrm{ha}^{-1}$ in 2013-14 and 2014-15 respectively) and found less important considering both adaptation and potential marketability. Though the variety Ranjan produced highest grain yield but it was statistically at par with the varieties BM-7, PL-6, PL-406, KLS-218 and Moitree. Lentil varieties produce higher yield under rich environments, as it is expected, while others yield better-than-average under poor environments but they fail to exploit better environmental conditions. Kundu et al. (2014) also observed significant differences in yield of the lentil crop variety through a study to assess the performances of sixteen pre-released and two standard varieties of bold seeded lentil for their productivity potential. They also observed significant differences in yield of the crop variety. The seed yield was maximum in PL-129 in both the year. The maximum productivity of lentil would be achieved when the maximum and minimum temperature during 100\% flowering ranged from 24.6 to 28.6 and 10.1 to $10.9 \mathrm{UC}$ respectively.

Pod yield was recorded at maturity stage before harvesting through the picking of pods from the crop plants and was statistically analyzed, which is presented in Table 2.The variety Ranjan also produced signifi- cantly higher pod yield (1213 and $1236 \mathrm{~kg} \mathrm{ha}^{-1}$ in both of the years respectively) followed by the variety PL406. The lowest pod yield was recorded from the variety BM-6 (951 and $973 \mathrm{~kg} \mathrm{ha}^{-1}$ in 2013-14 and 201415 respectively).

The data on stover yield of different varieties were statistically analyzed after threshing and drying of stovers of the crop. In case of stover yield, variety PL406 produced significantly highest stover yield (1755 and $1782 \mathrm{~kg} \mathrm{ha}^{-1}$ in 2013-14 and 2014-15 respectively) followed by the variety KLS-218 (1726 and $1772 \mathrm{~kg}$ $\mathrm{ha}^{-1}$ in 2013-14 and 2014-15 respectively) and BM-7 (1516 and $1542 \mathrm{~kg} \mathrm{ha}^{-1}$ in both of the years respectively). The variety BM- 6 showed the lowest stover yield (1220 and $1248 \mathrm{~kg} \mathrm{ha}^{-1}$ in 2013-14 and 2014-15 respectively). Biological yield was recorded after harvest by sun-drying of crops. The lentil variety PL-406 ( 2975 and $3126 \mathrm{~kg} \mathrm{ha}^{-1}$ in both of the years respectively) showed significantly higher biological yield among others followed by KLS-218 and Ranjan respectively, whereas BM 6 showed the lowest biological yield (2184 and $2226 \mathrm{~kg} \mathrm{ha}^{-1}$ in 2013-14 and 2014-15 respectively).

Shelling percentage was computed by dividing the seed yield by the pod yield and was expressed in percentage. Variety Subrata (65.62\%and $66.51 \%$ in 2013 -14 and 2014-15 respectively) gave significantly higher shelling percentage and closely followed by the variety Asha in first year and statistically at par in second year probably due to better seed recovering from pod of these varieties. Different variety positively effects the harvest index. In respect of harvest index, the variety HUL-57 showed significantly higher harvest index (30\% and $30.33 \%$ in 2013-14 and 2014-15 respectively) followed by Moitree and Subrata respectively. Variety PL-406 showed the lowest harvest index.

\section{Conclusion}

From the above result, it may be concluded that application of varietal trial of 10 lentil varieties, Ranjan cv. performed good result for producing the better growth 


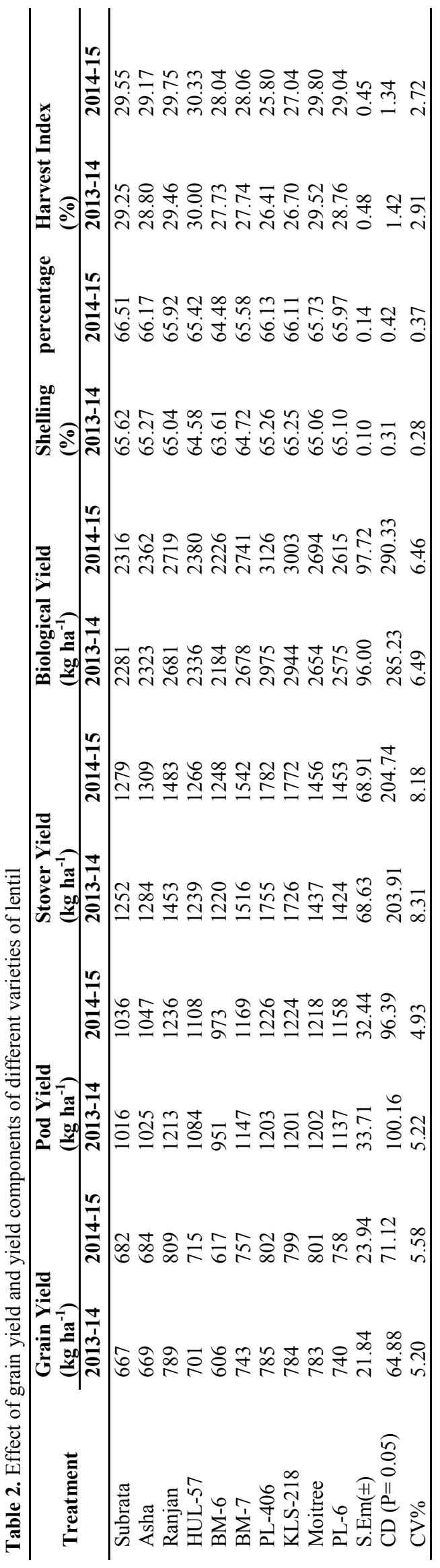

attributes and yields $789 \mathrm{~kg} \mathrm{ha}^{-1}$ in 2013-14 and $809 \mathrm{~kg}$ $\mathrm{ha}^{-1}$ 2014-15 under this soil and climatic condition immediately followed by PL-406 cv. and KLS-218 cv. Therefore, Ranjan cv. variety may have the opportunity to accept by the farmers in red and lateritic zone of West Bengal.

\section{ACKNOWLEDGEMENTS}

The authors gratefully acknowledge the Department of Agronomy, Soil Science, Agricultural Engineering, Plant Physiology and Animal Science ASEPAN, Palli Shiksha Bhavana, Visva-Bharati, Sriniketan, Birbhum, West Bengal for facilitating this experiment and providing all necessary facilities.

\section{REFERENCES}

Ali, M and Mishra, J P and Ahlawat, I P S and Kumar, $\mathrm{R}$ and Chauhan, Y. S. (1998). Effective management of legumes for maximizing biological nitrogen fixation and other benefits. In: Residual effects of legumes in rice and wheat cropping systems of the Indo-Gangetic plain: proceedings of the Workshop, 26-28 August 1998, Patancheru, India.

Ali, R. I., Awan, T. H., Ahmad, M. M., Saleem, U. and Akhta,r M. (2012). Diversification of rice-based cropping system to improve soil fertility, sustainable productivity and economics. $J$. of Animal and Plant Sci., 22(1):108-12

Das, A., Patel, D. P., Ramkrushna, G. I., Munda, G. C., Ngachan, S. V., Buragohain, J., Kumar, M. and Naropongla (2013). Crop diversification, crop and energy productivity under raised and sunken beds: results from a sevenyear study in a high rainfall organic production system. Biol. Agric. Hortic., http:// dx.doi.org/10.1080/01448765.2013.854709

Department of Agriculture and Cooperation (2014).Pocket Book of Agricultural Statistics. Directorate of Economics and Statistics.p-40.

Indian Institute of Pulses Research, Kanpur, (2015). E-pulses data book.

Jackson, M. L. (1973). Soil Chemical Analysis. Prentice Hall of India Pvt. Ltd., New Delhi, pp. 48-302.

Kundu, M.K., Maji, S., Basu, S., Nath, R. and Chakraborty, P. K. (2014). Evaluation of pre-released bold seeded lentil varieties for growth and yield potential in the Gangetic plains of West Bengal. J. Crop and Weed.,10(2): 111-117.

Muhr, G. K.; Dutta, N. D., Sankar, S. H., Laby, V. K. and Donahue, R. L. (1965). Soil Testing in India, U.S.A. for International Development Mission to India, New Delhi. pp. 39-46.

Olsen, S. R., Cole, C. V., Watanabe, F. S. and Dean, L. A. (1954). Estimation of available phosphorus by extraction with sodium bicarbonate. USDA Circular 939: 19.

Reddy, S. R. (2012). Agronomy of field crops. Kalyani publishers, New Delhi- 110002, pp. 337.

Roy, A., Aich, S. S., Bhowmick, M. K. and Biswas P. K. (2009). Response of lentil varieties to sowing time in the plains of West Bengal. J. Crop and Weed, 5(2):92-94.

Singh, A. K., Manibhushan, Bhatt, B. P., Singh, K. M. and 
Upadhyaya, A. (2013). An Analysis of Oilseeds and Pulses Scenario in Eastern India during 2050-51. J. of Agril. Sci.5 (1): 241- 249.

Singh, A. K., Meena, M. K. and Bharati, R.C. (2011). Sulphur and zinc nutrient management in rice lentil cropping system. In Proceedings of International Conference on Life Science Research for Rural and Agricultural Development, CPRS, Patna, Bihar, pp 66-67.

Srinivasarao, Ch., Venkateswarlu, B., Lal, R., Singh, A. K., Vittal, K. P. R., Kundu, S., Singh, S. R. and Singh, S. P.
(2012). Phosphorus Loss Potential and Phosphatase Activity under Phosphorus Fertilization in Long-Term Paddy Wetland Agroecosystems. Soil Sci. Soc. Am. J.76:161-167 doi:10.2136/ sssaj2011.0078.

Subbiah, B. V. and Asijha, G. L. (1956). Current Sci. vol. 251: (259-260).

Walkley, A. J. and Black, I. A. (1934). An estimation of Degtjaneff method for determining soil organic matter and a proposed medication of the chronic acid titration method, Soil Sci. 37: 29-39. 